\title{
Prêmio Belkin 1995
}

Oswaldo Paulo Forattini, professor catedrático da Faculdade de Saúde Pública da Universidade de São Paulo, especialista em insetos culicídeos, foi agraciado em $1995 \mathrm{com}$ o Prêmio John N. Belkin, anualmente concedido pela Associação Americana de Controle de Mosquitos (AMCA) a pesquisadores que se dedicam ao estudo de mosquitos transmissores de doenças.

Este prêmio foi instituído em 1980 em memória ao entomologista John Nicolas Belkin, falecido em 25 de abril daquele ano. Nesses quinze anos foram premiados dezesseis entomologistas (em 1986 houve dois premiados), em diferentes continentes, que tenham dedicado sua vida ao estudo de mosquitos vetores. O primeiro homenageado, em 1981, foi o sulafricano Botha de Meillon; posteriormente nove americanos foram premiados entre 1982 a 85,1987 a 88 e 1992 a 94, respectivamente, Lloyd E. Rozeboom, Kenneth L. Knight, Thomas J. Zavortink, Stanley J. Carpenter, James B. Kitzmiller, Alan Stone, Bruce A. Harrison, E. L. Peyton e Thomas G. Aitken. Um australiano em 1986. Elizabeth N. Marks. Dois ingleses, um em 1986 e outro em 1990, respectivamente, John A. Reid e Peter F. Mattingly. E finalmente nos anos 1989, 1991 e agora 1995, três sulamericanos, respectivamente o panamenho Pedro Galindo, o argentino José Pedro Duret e o brasileiro Oswaldo Paulo Forattini.

Nicolas Belkin foi um entomologista exemplar, um obstinado estudioso de mosquitos, ocupou inúmeros cargos acadêmicos e profissionais de destaque, quase sempre relacionados à entomologia; quando faleceu em 1980 era Professor Emérito de Entomologia da Universidade da California, em Los Angeles, LSA. Foi professor e pesquisador em várias áreas da zoologia de vertebrados e invertebrados, mas onde mesmo se aprofundou e destacou foi na entomologia, na qual produziu incontáveis publicaçôes de indubitável valor. Foi também um aficionado coletor de campo e participou de inúmeras campanhas de controle de mosquitos em diversas regiōes do mundo, o que lhe valeu o estabelecimento de metodologias de diversas técnicas de coleta, criação e registro, que atualmente são usadas por muitos trabalhadores em biologia e sistemática de culicídeos. Sua monumental obra "Mosquitoes of South Pacific" ou os meticulosos estudos sobre "Mosquitoes of Middle America" são provas do perfeccionismo. desvelo e dedicação que sempre imprimiu à sua produção. Os seus estudos em mosquitos foram um marco, suas descrições, seus desenhos esquemáticos e a nomenclatura que adotou passaram a servir de padrão para todos aqueles que trabalham com mosquitos. Belkin foi sem dúvida um líder. Após sua morte seus amigos e admiradores, entomologistas da AMCA, criaram o Fundo Memorial John Belkin para receber doações destinadas ao incentivo de estudos sobre mosquitos e, visando premiar os seguidores da tradição nesses estudos, criaram o Prêmio John Belkin.

Oswaldo Paulo Forattini, o primeiro brasileiro a receber esta homenagem e o $16^{\circ}$ entre todos, sem dúvida tem seguido esta tradição e, portanto fez jus à decisão da $\mathrm{AACM}$, que em seu $61^{\circ}$ Encontro em Portland, USA, em março de $1995 \mathrm{fez} \mathrm{a} \mathrm{entrega} \mathrm{ao} \mathrm{Dr.} \mathrm{Michael} \mathrm{Nelson,} \mathrm{entomologista} \mathrm{da} \mathrm{OPS,} \mathrm{que} \mathrm{pes-}$ soalmente passou a Forattini tão cara distinção. Desta forma, a comunidade científica americana e internacional faz reconhecimento ao trabalho de Forattini de toda uma vida dedicada à entomologia. De fato, desde 1949, imediatamente após sua formatura em medicina pela Universidade de São Paulo, ingressa na Faculdade de Higiene e Saúde Pública e passa a se dedicar exclusivamente à Entomologia. Mesmo quando produziu em 1980, seu livro texto sobre "Epidemiologia Geral", a primeira obra sobre o assunto em português, ou quando, em 1992 publicou seu livro "Ecologia, Epidemiologia e Sociedade", ou mesmo quando no período de 1979-1982 foi eleito diretor da Faculdade de Saúde Pública, não abandona, nem deixa decrescer sua produção na Entomologia. Sua volumosa obra sobre mosquitos nāo se limita à série "Entomologia Médica" mas, também, a inúmeros artigos sobre o assunto. Sua "Entomologia 
Médica", obra em quatro volumes, ainda hoje, após mais de 30 anos do início do lançamento, é a única em português e referência obrigatória para todos os que trabalham com mosquitos brasileiros ou sul americanos. Este trabalho não se restringe a apresentar detalhes dos aspectos da morfologia, sistemática e biologia desses mosquitos, mas estende esses conhecimentos à epidemiologia das doenças transmitidas por esses insetos, entrando ainda no contexto da profilaxia e controle dessas enfermidades. Seus estudos sobre Triatomíneos Vetores de Doença de Chagas inseridos em uma série de mais de duas dezenas de artigos sobre "Aspectos Ecológicos da Trypanosomíase Americana" continuam exclusivos e, além de ser bibliografia obrigatória para investigadores na biologia e controle desses vetores, têm servido de auxílio no delineamento do controle dos órgåos responsáveis pela profilaxia da Doença de Chagas no Estado de Sāo Paulo.

Forattini continua, mesmo compulsoriamente aposentado em fins de 1993, a produzir como sempre produziu. Mais recentemente está desenvolvendo projeto de estudo para determinação do potencial transmissor de malária na Ilha Comprida, localizada no Vale do Ribeira, Estado de São Paulo, região na qual trabalha há mais de vinte anos $e$ onde tem produzido uma série de relevantes observações sobre comportamento de mosquitos transmissores, entre essas destacando-se a determinação do papel vetor do Aedes scapularis na transmissão do vírus Rocio. E seu plano mais novo para um futuro próximo consiste na elaboração do tratado de "Culicidologia Médica", em cujo planejamento está prevista a inclusão de glossário em português para estudos morfológicos e taxionômicos em mosquitos culicídeos.

A AMCA quando homenageou Oswaldo Paulo Forattíni premiou alguém que como John Nicolas Belkin, dedicou e se dedica exclusivamente à Entomologia, garantindo assim, mais uma vez, a magnitude e a continuidade da Tradição do prêmio John Belkin. 


\section{Belkin Prize - 1995}

Oswaldo Paulo Forattini, full professor of the School of Public Health of the University of S. Paulo, specialist in culicidae insects, has been awarded the John N. Belkin Prize, given annually by the American Mosquito Control Association (AMCA) to research workers in the field of disease transmitting mosquitoes, in 1995.

This prize was instituted in 1980 in memory of the entomologist John Nicholas Belkin who died on April 25th of that same year. Sixteen entomologists from different continents, who have dedicated their lives to the study of vector mosquitoes, have received the award over these fifteen years (in 1986 there were two prize-winners). The first to receive the award, in 1981, was the South-African Botha de Meillon. Then nine Americans received it in the years: 1982-85, 1987, 1988 and 1992-94; they were, in chronological order: Lloyd E. Rozeboom, Kenneth H. Knight, Thomas J. Zavortink, Stanley J. Carpenter, Jame B. Kitzmiller, Allan Stone, Bruce A. Harrison, E. L. Peyton and Thomas G. Aitken. An Australian, Elizabeth N. Marks, received the award in 1986, and two Englishmen, John A. Reid, in 1986, and Peter F. Mattingly, in 1990. Finally, three South Americans, were similarly honored: the Panamanian Pedro Galindo, the Argentinian José Pedro Duret and now the Brazilian Oswaldo Paulo Forattini, in 1989, 1991 and 1995 , respectively.

Nicolas Belkin was an exemplary entomologist, a determined student of mosquitoes who filled numerous outstanding academic and professional positons, almost all of them related to entomology; on the occasion of his death in 1980 he was Emeritus Professor of Entomology of the University of California, Los Angeles, USA. He was a professor and research worker in various branches of the zoology of vertebrates and invertebrates, but the subject in which he really specialized was entomology, on which he produced innumerable books of unquestionable value. He was also an enthusiastic collector in the field and took part in numerous mosquito control campaigns in various regions of the world. This wide experience led him to establish the methodology of various techniques for collection, breeding and registration, which are used at the present time by many workers in biology and the systematic study of culicidae. His monumental work "Mosquitoes of the South Pacific" or his meticulous studies in "Mosquitoes of Middle America" are demonstrations of the perfectionism, zeal and dedication which characterize his production. His studies on mosquitoes constituted a land-mark, his descriptions, his schematic drawings and the nomenclature which he adopted came to serve as standards for all who work on mosquitoes. Belkin was, without doubt, a leader. After his death his friends and admirers, entomologists of the AMCA, established the John Belkin Memorial Fund to receive donations for the purpose of incentivating studies on mosquitoes and, with a view to making an award to followers of the tradition in these studies, created the John Belkin Prize.

Oswaldo Paulo Forattini, the first Brazilian to be honored in this way and the 16th in the series, has without doubt been faithful to this tradition and has therefore deserved the decision of the AMCA, which, in its 61 st Meeting in Portland, USA, in March 1995, presented the award to Dr. Michael Nelson, entomologist of the PAHO, who delivered the precious distinction to Forattini. Thus the American and international scientific community has recognised the dedication of Forattini's life's work to entomology. In 1949, immediately after his graduation in Medicine at the University of S. Paulo, he entered the School of Hygiene and Public Health and has since dedicated his attention exclusively to entomology. Not even after producing his textbook on "General Epidemiology", the first work on the subject in Portuguese, in 1980, nor when in 1992 he published his book "Ecology, Epidemiology and Society" nor even during the period from 1979 to 1982 when he was Director of the School of Public Health, did he abandon or permit his production on entomology to diminish. His comprehensive work on mosquitoes is not limited to the series "Medical Entomology" but covers also innumerable articles on the subject. His "Medical Entomology", a four-volume work, is still today, more than thirty years after its original publication, the 
only one in Portuguese and is an indispensable work of reference for all who work on Brazilian or South American mosquitoes. This work is not restricted to a presentation of details of the morphology, systematic and biology of these insects, but extends this knowledge to the epidemiology of the diseases transmitted by these insects and, still further, goes into the prophylactic treatment and control of those disease. His studies on "Triatomide Vectors of Chagas' Disease" included in a series of more than a score of articles on "Ecological Aspects of American Trypanosomiasis" are still today unequalled and as well as being obligatory reading for researchers into the biology and control of these vectors, have been useful in the delineation of the control of the government organs responsible for the prophylactic treatment of Chagas' Disease in the State of S. Paulo.

Forattini, despite his compulsory retirement at the end of 1993 , continues to produce just as before. More recently he has been undertaking a study project to discover the potential carrier of malaria on "Ilha Comprida" in the Ribeira River Valley, S. Paulo State, a region in which he has worked for more than twenty years and on which he has produced a series of important observations regarding the behavior of carrier mosquitoes among which the determination of the vector role of Aedes scapularis in the transmission of the Rocio virus is specially noteworthy. His latest plan for the immediate future is the preparation of a treatise on "Medical Culicidology", in the planning for which a Portuguese language glossary for the morphologic and taxonomic studies on culicidae mosquitoes is will be included.

The AMCA, when it paid its tribute to Oswaldo Paulo Forattini, gave the award to someone who, like John Nicholas Belkin, has dedicated his life exclusively to entomology, thus guaranteeing, once more, the magnitude and continuity of the tradition enshrined in represented by symbolized by the John Belkin Prize. 